\title{
PERSEPSI PASIEN MENGENAI KETEPATAN TINDAKAN RUJUKAN PESERTA BPJS KESEHATAN PADA MASA PANDEMI DI PUSKESMAS TAHUN 2020
}

\section{PATIENT PERCEPTIONS REGARDING THE APPROPRIATENESS OF REFERRAL ACTIONS FOR BPJS PARTICIPANTS DURING THE PANDEMIC AT PUBLIC HEALTH CENTER IN 2020}

\author{
Yuniko Ibnu Latif, Fajar Ariyanti* \\ Program Studi Kesehatan Masyarakat, Fakultas Ilmu Kesehatan, \\ Universitas Islam Negeri Syarif Hidayatullah Jakarta \\ Jalan Kertamukti, Pisangan, Ciputat 15419, Tangerang Selatan, Indonesia \\ *email: fajar.ariyanti@uinjkt.ac.id
}

\begin{abstract}
The ratio of referral of Puskesmas to hospitals in several regions in Indonesia is relatively high and has not met the ideal standard of $15 \%$. This also happened to the Jurangmangu Health Center in South Tangerang. The cause of the referral problem was the desire of the patient who wanted to be referred, the lack of consumables and medicines at the health centre. The accuracy of the referral action can be seen by perception. The public perception regarding the accuracy of referral in general can be seen from the experience of referrals to health facilities. The purpose of this study was to identify the factors that related to patient perceptions regarding the Appropriateness of referral actions for BPJS participants during the pandemi at Jurang Mangu Public Health Center. Design of this study was quantitative using a cross sectional approach. The sample in this study amounted to 123 patients who participated in the BPJS program at the Jurang Mangu Health Center who had been referred. The statistical test used chi-square with CI 95\%. The results showed that there was association between the information about the referral $(p=0.001)$ with patient perceptions regarding the Appropriateness of referral actions for BPJS Participants during the Pandemi at Jurang Mangu Public Health Center. Meanwhile, the variables of knowledge, attitudes of health workers, and the availability of infrastructure had no association. Therefore, Public Health Center should do collaboration with the BPJS office for socialization of referrals and providing media information about referral services for patients.
\end{abstract}

Keywords: perception, refferal, BPJS, Public Health Center

\begin{abstract}
Abstrak
Angka rasio rujukan Puskesmas ke rumah sakit di beberapa daerah di Indonesia relatif tinggi dan belum memenuhi standar ideal yaitu $15 \%$. Hal ini juga terjadi pada Puskesmas Jurangmangu di Tangerang Selatan. Penyebab terjadinya masalah rujukan yaitu pasien yang memang ingin untuk dirujuk hingga kurangnya bahan habis pakai dan obat-obatan di puskesmas. Ketepatan tindakan rujukan dapat diketahui salah satunya dari persepsi. Persepsi masyarakat mengenai ketepatan rujukan secara umum dapat diketahui dari pengalaman rujukan ke fasilitas kesehatan. Tujuan Penelitian ini adalah untuk mengetahui faktor-faktor yang berhubungan dengan persepsi pasien mengenai ketepatan tindakan rujukan peserta BPJS Kesehatan pada masa pandemi di Puskesmas Jurang Mangu. Jenis penelitian ini adalah kuantitatif dengan menggunakan pendekatan cross sectional. Sampel pada penelitian ini berjumlah 123 pasien peserta BPJS Kesehatan di Puskesmas Jurang Mangu yang pernah dirujuk. Analisis data menggunakan uji chi-square dengan confidence interval $95 \%$. Hasil penelitian menunjukan bahwa terdapat hubungan yang signifikan antara informasi tentang rujukan $(p$-value $=0,001)$ dengan persepsi pasien mengenai
\end{abstract}


ketepatan tindakan rujukan peserta BPJS Kesehatan pada masa pandemi. Sedangkan variabel pengetahuan, sikap tenaga kesehatan, dan ketersediaan sarana prasarana tidak memiliki hubungan yang signifikan. Untuk itu, pihak puskesmas diharapkan dapat melakukan kerja sama dengan BPJS Kesehatan dan kader kesehatan untuk sosialisasi terkait rujukan BPJS Kesehatan dan dapat menyediakan media informasi mengenai layanan rujukan untuk pasien.

Kata Kunci: persepsi, rujukan, BPJS Kesehatan, Puskesmas

\section{PENDAHULUAN}

Jaminan Kesehatan diselenggarakan dengan tujuan menjamin agar peserta memperoleh manfaat pemeliharaan kesehatan dan perlindungan dalam memenuhi kebutuhan dasar kesehatan. Undang-Undang No. 40 tahun 2004 Tentang Sistem Jaminan Sosial Nasional ini mengamanatkan bahwa jaminan sosial wajib bagi seluruh penduduk melalui suatu Badan Penyelenggara Jaminan Sosial (BPJS). Badan Penyelenggara Jaminan Kesehatan (BPJS) Kesehatan beroperasi mulai tanggal 1 Januari 2014. Undang-Undang Nomor 24 Tahun 2011 tentang Badan Penyelenggara Jaminan Sosial, secara tegas menyatakan bahwa BPJS yang dibentuk dengan Undang-Undang BPJS adalah badan hukum publik.

BPJS merupakan lembaga yang didirikan untuk mencapai Universal Health Coverage (UHC) yang merupakan komitmen bersama negara-negara anggota World Health Organization (WHO) termasuk Indonesia. Universal Health Coverage adalah program yang memastikan masyarakat memiliki akses untuk mendapatkan pelayanan kesehatan tanpa harus mengahadapi kesulitan finansial. Hal ini ditunjang dengan pelayanan fasilitas kesehatan yang berkualitas (Kementerian Kesehatan, 2018). Seluruh warga Indonesia wajib terdaftar sebegai peserta JKN, hal ini merupakan upaya dalam mendorong partisipasi masyarakat dalam mencapai UHC (Kurniawati and Rachmayanti, 2018).

Berdasarkan cakupannya, kepesertaan program JKN hingga 31 Mei 2020 sudah mencapai 220,6 juta $(83 \%$ penduduk Indonesia). Masih ada sisa sekitar $15 \%$ yang menjadi tugas kita untuk mencapai target RPJMN (Muhadjir, 2020). Hal ini untuk mewujudkan UHC di Indonesia sesuai target yang ditetapkan. Komisioner Dewan Jaminan Sosial Nasional (DJSN) menjelaskan bahwa setiap bulan BPJSK mentransfer dana kapitasi kepada puskesmas dengan besaran sesuai jumlah peserta yang tertanggung, tetapi ternyata tidak terpakai seluruhnya. Hal ini menyebabkan sisa lebih pembiayaan anggaran (Silpa) (Ansori, 2019).

Berdasarkan Peraturan Badan Penyelenggara Jaminan Sosial No. 2 Tahun 2015 standar idealnya rujukan puskesmas ke Rumah Sakit tidak lebih dari 15\% dan rasio rujukan non spesialistik pada zona aman sebesar kurang dari 5\% (BPJS Kesehatan, 2015). Rasio rujukan merupakan perbandingan antara angka jumlah pasien yang dirujuk dengan angka jumlah total kunjungan pasien dikalikan dengan 100 .

Menurut (Ansori, 2019) rata-rata puskesmas belum dapat menuntaskan 144 diagnosa penyakit dan hanya bisa menyelesaikan kurang dari 100 diagnosa penyakit selebihnya dirujuk ke fasilitas kesehatan tingkat lanjut atau rumah sakit. Seharusnya BPJS Kesehatan membayar lebih rendah dana kapitasi kepada puskesmas yang tidak dapat menangani 144 diagnosa penyakit. Penelitian (Alfiani and Nurwahyuni, 2014) juga menunjukkan rasio rujukan peserta sebesar 32,3\% untuk kriteria 144 diagnosa penyakit, angka tersebut lebih tinggi dari angka rujukan non spesialistik yang BPJS Kesehatan telah tetapkan yaitu sebesar $15 \%$.

Pada bulan April 2020 seiring dengan penerapan Pembatasan Sosial Berskala Besar (PSBB) di Tangerang Selatan angka rasio rujukan masih relatif tinggi. PSBB diberlakukan karena merebaknya pandemic Corona Virus Disease (COVID-19). Kasus COVID-19 di Indonesia telah dilaporkan pada tanggal 2 Maret 2020 dengan jumlah dua kasus (WHO, 2020a). Pada 31 Maret 2020 jumlah kasus yang terkonfirmasi sebesar 1528 kasus dengan 136 kematian. Tingkat mortalitas COVID-19 di Indonesia mencapai 8,9\%, yang merupakan angka mortalitas tertinggi di Asia Tenggara (Susilo et al., 2020; WHO, 2020b, 2020a)

Berdasarkan studi pendahuluan di Puskesmas Jurang Mangu didapatkan bahwa rata-rata rasio rujukan pasien peserta BPJS di Puskesmas Jurang Mangu pada Bulan Agustus 
2019 hingga Februari 2020 masih diatas 20\%. Presentase ini mengalami peningkatan yang drastis pada Bulan Maret 2020 yaitu sebesar 29,6\% dan bulan April 2020 sebesar 51,9\%. Hal ini sangat jauh dari target pemenuhan indikator komitmen pelayanan yang telah ditetapkan oleh BPJS Kesehatan yaitu kurang dari $15 \%$ perbulan (BPJS Kesehehatan and Kementerian Kesehatan, 2017).

Penelitian (Alawi, Junadi and Latifah, 2015) menjelaskan bahwa faktor-faktor yang berhubungan dengan tingginya rujukan kasus non spesialitik pasien Jaminan Kesehatan Nasional pada Puskesmas di Kabupaten Sukabumi adalah wilayah, kecukupan obat, kecukupan alat kesehatan dan jarak puskesmas. Penelitian (Purwati, 2017) menjelaskan bahwa penyebab terjadinya masalah rujukan yaitu keinginan pasien yang memang ingin untuk dirujuk, kurangnya bahan habis pakai dan obatobatan di puskesmas, kurangnya atau tidak adanya peralatan medis di puskesmas, dan kurangnya tenaga Sumber Daya Manusia (SDM) khususnya tenaga dokter. Dalam penelitian ini, ketepatan tindakan rujukan dapat diketahui salah satunya dari persepsi. Hal ini sejalan dengan penelitian (Nurlinawati, 2018) didapatkan bahwa persepsi masyarakat mengenai ketepatan rujukan secara umum dapat diketahui dari pengalaman rujukan ke fasilitas kesehatan yang terlihat dari seluruh informan memiliki pengalaman yang berbeda.

Penelitian ini bertujuan untuk mengetahui faktor-faktor yang berhubungan dengan persepsi pasien mengenai ketepatan tindakan rujukan peserta BPJS Kesehatan pada masa pandemi di Puskesmas Jurang Mangu, Tangerang Selatan

\section{METODE PENELITIAN}

Jenis penelitian ini adalah kuantitatif dengan menggunakan pendekatan cross sectional. Populasi dalam penelitian ini adalah seluruh pasien peserta BPJS Kesehatan yang dirujuk di Puskesmas Jurang Mangu sebanyak 6.378. Sampel pada penelitian ini berjumlah 123 pasien peserta BPJS di Puskesmas Jurang Mangu yang didapatkan dari perhitungan rumus Sampel menggunakan rumus uji beda dua proporsi (Lemeshow, Jr, \& Klar, 1990).

Teknik pengumpulan data penelitian ini adalah incidental sampling. Sumber data dalam penelitian ini adalah data primer. Pengambilan data dilakukan pada bulan Juli 2020 melalui Google form atau kuesioner online pada pasien peserta BPJS yang dirujuk ke Fasilitas Kesehatan Tingkat Lanjut

Metode analisis data dalam penelitian ini adalah analisis univariat dan bivariat. Analisis bivariat untuk mencari hubungan antara variabel dependen yaitu persepsi pasien mengenai mengenai ketepatan tindakan rujukan dengan variabel independen yang terdiri dari pengetahuan, sikap tenaga kesehatan, ketersediaan sarana prasarana, dan informasi tentang rujukan. Adapun uji statistik menggunakan uji chi square dengan batas kemaknaan uji statistik 5\% ( $p$-value < 0,05).

Penelitian ini telah mendapatkan persetujuan dari komite etik penelitian Fakultas Ilmu Kesehatan Universitas Islam Negeri Syarif Hidayatullah berdasarkan surat dengan nomor UN.01/F10/KP.01.1/KE.SP/08.08.015/2020.

\section{HASIL DAN PEMBAHASAN}

\section{Persepsi Pasien Mengenai Ketepatan Tindakan Rujukan Peserta BPJS Kesehatan pada Masa Pandemi}

Berdasarkan Tabel 1, diketahui bahwa dari 123 responden, mayoritas responden memiliki persepsi sesuai mengenai ketepatan tindakan rujukan peserta BPJS Kesehatan pada masa pandemi di Puskesmas Jurang Mangu tahun 2020 yaitu sebanyak 87 responden $(50,4 \%)$, sedangkan responden yang memiliki persepsi tidak sesuai mengenai ketepatan tindakan rujukan pasien peserta BPJS Kesehatan pada masa pandemi yaitu sebanyak 36 responden $(49,6 \%)$.

Hal ini disebabkan karena pada masa pandemi, masih banyak responden pasien peserta BPJS Kesehatan di Puskesmas Jurang Mangu yang datang saat sakit dan langsung meminta rujukan dari puskesmas untuk menuju fasilitas kesehatan tingkat lanjut atau rumah sakit. Bahkan masih terdapat banyak responden yang bersikeras meminta rujukan ke puskesmas walaupun tidak disarankan oleh dokter atau petugas kesehatan. Selain itu, pasien juga meminta rumah sakit tertentu sesuai keinginan dari pasien. Hal tersebut menjelaskan bahwa masih banyak masyarakat yang belum mengkhawatirkan keadaan pandemi COVID-19 seperti saat ini. Rumah Sakit merupakan tempat yang memungkinkan orang untuk dapat terinfeksi berbagai macam virus dengan mudah. Sebaiknya pasien peserta BPJS Kesehatan di Puskesmas Jurang Mangu tidak bersikeras meminta rujukan jika tidak disarankan dokter 
guna mengurangi risiko tertularnya Covid-19 ini.

Hal tersebut tidak sesuai dengan ketetapan BPJS Kesehatan Tahun 2014 pada Panduan Praktis Sistem Rujukan Berjenjang yang menyebutkan bahwa peserta yang ingin mendapatkan pelayanan yang tidak sesuai dengan sistem rujukan temasuk dalam kategori pelayanan yang tidak sesuai dengan prosedur yang ada. Pasien dapat dirujuk ke pelayanan kesehatan yang lebih tinggi apabila memang membutuhkan pelayanan spesialistik atau sub spesialistik, puskesmas memiliki keterbatasan fasilitas, peralatan dan/atau ketenagaan (Kementerian Kesehatan, 2012). Ketentuan tersebut juga tetap berlaku pada masa pandemi seperti saat ini.

\section{a. Pengetahuan Pasien}

Berdasarkan Tabel 1, diketahui bahwa dari 123 responden, terdapat 78 responden yang memiliki pengetahuan baik terkait rujukan BPJS Kesehatan pada masa pandemi dengan presentase $63,4 \%$, sedangkan responden yang memiliki pengetahuan tidak baik sebanyak 45 responden dengan presentase $36,6 \%$.

\section{b. Sikap Tenaga Kesehatan Terhadap Pasien}

Berdasarkan Tabel 1, diketahui bahwa dari 123 responden terdapat 72 responden $(58,5 \%)$ yang berpendapat sangat setuju, 48 responden $(39 \%)$ yang berpendapat setuju, 2 responden $(1,6 \%)$ berpendapat tidak setuju dan 1 responden $(0,8 \%)$ yang berpendapat sangat tidak setuju terhadap sikap petugas kesehatan dalam pelayanan rujukan pada masa pandemi di Puskesmas Jurang Mangu.

\section{c. Ketersediaan Sarana dan Prasarana}

Berdasarkan Tabel 1, diketahui bahwa dari 123 responden terdapat 110 responden $(89,4 \%)$ yang berpendapat bahwa sarana dan prasarana tersedia dalam rujukan pasien peserta BPJS Kesehatan pada masa pandemi di Puskesmas, sedangkan sebanyak 23 responden $(10,6 \%)$ berpendapat bahwa sarana dan prasarana dalam rujukan pasien peserta BPJS Kesehatan pada masa pandemi tidak tersedia di Puskesmas.

\section{d. Informasi Rujukan}

Berdasarakan Tabel 1, diketahui bahwa dari 123 responden terdapat 62 responden $(50,4 \%)$ yang pernah mendapatkan informasi terkait rujukan BPJS Kesehatan pada masa pandemi, sedangkan sebanyak 61 responden $(49,6 \%)$ tidak pernah mendapatkan informasi terkait rujukan BPJS Kesehatan pada masa pandemi.

Tabel 1. Distribusi Frekuensi Variabel Penelitian

\begin{tabular}{lcc}
\hline \multicolumn{1}{c}{ Variabel } & $\begin{array}{r}\text { Jumlah } \\
(\mathbf{n = 1 2 3})\end{array}$ & $\mathbf{\%}$ \\
\hline Persepsi Rujukan & & \\
$\quad$ Sesuai & 87 & 50,4 \\
$\quad$ Tidak Sesuai & 36 & 49,6 \\
Pengetahuan & & \\
$\quad$ Baik & 78 & 63,4 \\
$\quad$ Tidak Baik & 45 & 36,6 \\
Sikap Tenaga & & \\
Kesehatan & & \\
$\quad$ Sangat Setuju & 72 & 58,5 \\
$\quad$ Setuju & 48 & 39 \\
$\quad$ Tidak Setuju & 2 & 1,6 \\
$\quad$ Sangat Tidak Setuju & 1 & 0,8 \\
Sarana dan Prasarana & & \\
$\quad$ Tersedia & 110 & 89,4 \\
$\quad$ Tidak Tersedia & 23 & 10,6 \\
Informasi Rujukan & & \\
$\quad$ Pernah & 62 & 50,4 \\
$\quad$ Tidak Pernah & 61 & 49,6 \\
\hline$\quad$
\end{tabular}

\section{Hubungan Antara Pengetahuan dengan Persepsi Pasien Mengenai Ketepatan Tindakan Rujukan}

Berdasarkan Tabel 2, dapat dilihat bahwa dari 36 responden yang memiliki persepsi tidak sesuai mengenai ketepatan tindakan rujukan, 16 responden $(35,6 \%)$ memiliki pengetahuan tidak baik dan 20 responden $(25,6 \%)$ memiliki pengetahuan baik. Sedangkan responden yang memiliki persepsi sesuai mengenai ketepatan tindakan rujukan, 29 responden $(64,4 \%)$ memiliki pengetahuan tidak baik dan 58 responden $(74,4 \%)$ memiliki pengetahuan baik. Nilai $p$-value sebesar 0,338 yang artinya tidak ada hubungan yang signifikan antara pengetahuan dengan persepsi pasien mengenai ketepatan tindakan rujukan peserta BPJS Kesehatan pada masa pandemi di Puskesmas Jurang Mangu tahun 2020.

Hasil analisis menunjukkan jumlah responden yang berpengetahuan baik lebih banyak dibandingkan responden yang berpengetahuan tidak baik. Hal itu menjelaskan bahwa, banyak masyarakat atau responden yang mengetahui tentang rujukan BPJS Kesehatan. Mayoritas responden dalam penelitian ini memahami bahwa pasien BPJS Kesehatan akan menerima rujukan harus sesuai dengan 
prosedur yang berlaku. Tetapi, masih terdapat responden yang beranggapan bahwa Puskesmas hanya sebagai tempat meminta rujukan untuk ke fasilitas kesehatan tingkat lanjut atau Rumah Sakit, sehingga menyebabkan rujukan pasien peserta BPJS Kesehatan yang tidak sesuai dengan ketentuan yang seharusnya. Penelitian ini sejalan dengan penelitian (Siregar, 2018) yang menyatakan bahwa tidak ada hubungan antara pengetahuan responden dengan rujukan di Puskesmas. Penelitian serupa tentang persepsi petani terhadap program lumbung pangan yang dilakukan oleh (Dwirayani and Suciati, 2017) menjelaskan bahwa pengetahuan dinilai cukup penting, karena kurangnya pengetahuan yang dimiliki dapat mempengaruhi munculnya persepsi responden.

Tabel 2. Hubungan Variabel dengan Persepsi Ketepatan Tindakan Rujukan

\begin{tabular}{|c|c|c|c|c|c|c|c|}
\hline \multirow{3}{*}{ Variabel } & \multicolumn{4}{|c|}{$\begin{array}{c}\text { Persepsi } \\
\text { Ketepatan } \\
\text { Tindakan } \\
\text { Rujukan }\end{array}$} & \multirow{2}{*}{\multicolumn{2}{|c|}{ Total }} & \multirow[t]{3}{*}{$p$-value } \\
\hline & \multicolumn{2}{|c|}{$\begin{array}{c}\text { Tidak } \\
\text { Sesuai }\end{array}$} & \multicolumn{2}{|c|}{ Sesuai } & & & \\
\hline & $\mathbf{N}$ & $\%$ & $\mathbf{N}$ & $\%$ & $\mathbf{N}$ & $\%$ & \\
\hline \multicolumn{8}{|l|}{$\overline{\text { Pengetahuan }}$} \\
\hline Tidak Baik & 16 & 35,6 & 29 & 64,4 & 45 & 100 & 0,338 \\
\hline Baik & 20 & 25,6 & 58 & 74,4 & 78 & 100 & \\
\hline \multicolumn{8}{|c|}{ Sikap Tenaga } \\
\hline \multicolumn{8}{|l|}{ Kesehatan } \\
\hline $\begin{array}{l}\text { Sangat Tidak } \\
\text { Setuju }\end{array}$ & 0 & 0 & 1 & 100 & 1 & 100 & 0,721 \\
\hline Tidak setuju & 0 & 0 & 2 & 100 & 2 & 100 & \\
\hline Setuju & 15 & 31,3 & 33 & 68,7 & 48 & 100 & \\
\hline Sangat Setuju & 21 & 29,2 & 51 & 70,8 & 72 & 100 & \\
\hline \multicolumn{7}{|c|}{ Ketersediaan } & \\
\hline \multicolumn{8}{|l|}{ Prasarana } \\
\hline $\begin{array}{l}\text { Tidak } \\
\text { Tersedia }\end{array}$ & 2 & 15,4 & 11 & 84,6 & 13 & 100 & 0,4 \\
\hline Tersedia & 34 & 30,9 & 76 & 69,1 & 110 & 100 & \\
\hline \multicolumn{8}{|l|}{ Informasi } \\
\hline Rujukan & & & & & & & \\
\hline Tidak Pernah & 24 & 45,3 & 29 & 54,7 & 53 & 100 & 0,001 \\
\hline Pernah & 12 & 17,1 & 58 & 82,9 & 70 & 100 & \\
\hline
\end{tabular}

\section{Hubungan Antara Sikap Tenaga Kesehatan dengan Persepsi Pasien Mengenai Ketepatan Tindakan Rujukan}

Berdasarkan Tabel 2, dapat dilihat dari 36 responden yang memiliki persepsi tidak sesuai mengenai ketepatan tindakan, sebanyak 15 responden $(31,3 \%)$ berpendapat setuju dan 21 responden $(29,2 \%)$ berpendapat sangat setuju dengan sikap petugas kesehatan. Sedangkan, responden yang memiliki persepsi sesuai mengenai ketepatan tindakan rujukan, 1 responden berpendapat sangat tidak setuju, 2 responden tidak setuju, 33 responden $(68,7 \%)$ setuju, dan 51 responden $(70,8 \%)$ sangat setuju dengan sikap petugas kesehatan. Nilai $p$-value $=0,721$ yang artinya tidak ada hubungan yang signifikan sikap dengan persepsi pasien mengenai ketepatan tindakan rujukan peserta BPJS Kesehatan pada masa pandemi di Puskesmas Jurang Mangu tahun 2020. Berdasarkan hasil tersebut diketahui bahwa sikap petugas tidak mempengaruhi besarnya angka rujukan pasien peserta BPJS Kesehatan pada masa pandemi di Puskesmas Jurang Mangu. Pasien peserta BPJS beranggapan bahwa sikap petugas kepada pasien sangat baik di dalam pelayanan dalam memberikan rujukan ke fasilitas kesehatan tingkat lanjut.

Penelitian yang dilakukan oleh Setyaningsih (2012) tentang hubungan antara persepsi dengan sikap menjelaskan bahwa semakin baik sikap maka akan semakin positif persepsi. Begitu pun sebaliknya, jika persepsi negatif maka akan berpengaruh pula pada sikapnya yang akan cenderung negatif. Namun dalam pelayanan rujukan sikap petugas bukanlah hal yang utama, mengingat bahwa banyak faktor yang harus dipertimbangkan diantaranya adalah ketersediaan layanan dan penerimaan pasien. Penelitian Omole, et. al, (2017) menunjukkan bahwa rujukan harus dilakukan berdasarkan permintaan pasien dan keluarganya bukan oleh dokter atau petugas kesehatan. Perspektif ini dalam jangka panjang berkontribusi terhadap peningkatan jumlah rujukan mandiri di fasilitas kesehatan rujukan. Selain itu, penelitian Scaioli, et. al, (2019) menunjukkan bahwa komunikasi yang baik menjadi hal yang penting dalam ketepatan tindakan rujukan.

\section{Hubungan Antara Ketersediaan Sarana dan Prasarana dengan Persepsi Pasien Mengenai Ketepatan Tindakan Rujukan}

Berdasarkan tabel 2, dapat dilihat dari 36 responden yang memiliki persepsi tidak sesuai mengenai ketepatan tindakan rujukan, sebanyak 2 responden $(15,4 \%)$ berada pada ketegori ketidaktersediaan sarana dan prasarana dan 34 responden $(30,9 \%)$ pada kategori ketersediaan sarana dan prasarana. Sedangkan responden yang memiliki persepsi sesuai mengenai ketepatan tindakan rujukan, 11 responden $(84,6 \%)$ pada kategori ketidaktersediaan sarana dan prasarana dan 76 responden $(69,1 \%)$ pada 
kategori ketersediaan sarana dan prasarana. Nilai $p$-value sebesar 0,400 yang artinya tidak ada hubungan yang signifikan antara ketersediaan sarana dan prasarana dengan persepsi pasien mengenai ketepatan tindakan rujukan peserta BPJS Kesehatan pada masa pandemi di Puskesmas Jurang Mangu tahun 2020.

Hasil penelitian menunjukan bahwa Puskesmas Jurang Mangu pada masa pandemi seperti saat ini, memiliki ketersediaan obatobatan yang cukup sehingga kebutuhan obatobatan dapat terpenuhi, serta alat kesehatan yang cukup memadai dan alat kesehatan yang masih dapat berfungsi sebagai penunjang kegiatan pelayanan kesehatan kepada pasien di Puskesmas, pada masa pandemi saat ini Puskesmas Jurang Mangu juga memiliki sarana untuk cuci tangan (air mengalir, sabun, dan/atau hand sanitizer). Hal tersebut menjelaskan bahwa Puskesmas Jurang Mangu pada masa pandemi seperti saat ini mengikuti protokol kesehatan sebagaimana disebutkan dalam petunjuk teknis pelayanan Puskesmas pada masa pandemi COVID-19 yang dibuat oleh Kementerian Kesehatan, 2020. Penelitian tentang persepsi yang telah dilakukan (Hanifah, Suryoputro and Arso, 2018) menjelaskan bahwa sarana prasarana atau fasilitas termasuk dalam lingkungan fisik dan lingkungan fisik yang mendukung akan membuat seseorang memiliki persepsi yang baik terhadap kualitas layanan. Sebaliknya, apabila lingkungan fisik tidak mendukung maka persepsi akan cenderung rendah dalam menilai kualitas layanan.

Salah satu sarana prasarana yang dibutuhkan dalam masa pandemi adalah APD bagi petugas kesehatan. Penelitian Setiati dan Azwar (2020) menjelaskan bahwa APD sangat penting digunakan oleh petugas kesehatan dalam pelayanan sehingga petugas merasa aman saat bertugas, hal tersebut mengurangi risiko penularan dari petugas kesehatan ke pasien mau pun sebaliknya.

\section{Hubungan Informasi Rujukan dengan Persepsi Pasien Mengenai Ketepatan Tindakan Rujukan}

Berdasarkan Tabel 2, dapat dilihat bahwa dari 36 responden yang memiliki persepsi tidak sesuai mengenai ketepatan tindakan rujukan, sebanyak 24 responden $(45,3 \%)$ pada kategori tidak pernah mendapatkan informasi rujukan dan 12 responden $(17,1 \%)$ pada kategori pernah mendapatkan informasi rujukan. Sedangkan responden yang memiliki persepsi sesuai mengenai ketepatan tindakan rujukan, sebanyak 29 responden $(54,7 \%)$ pada kategori tidak pernah mendapatkan informasi rujukan dan sebanyak 58 responden $(82,9 \%)$ pada kategori pernah mendapatkan informasi rujukan. Nilai $p$ value $=0,001$ yang artinya ada hubungan yang signifikan antara informasi rujukan dengan persepsi pasien mengenai ketepatan tindakan rujukan peserta BPJS Kesehatan pada masa pandemi di Puskesmas Jurang Mangu tahun 2020.

Berdasarkan Tabel 2, terdapat hubungan yang signifikan antara informasi tentang rujukan dengan persepsi pasien mengenai mengenai ketepatan tindakan rujukan peserta BPJS Kesehatan pada masa pandemi di Puskesmas Jurang Mangu ( $p$-value $=0,001)$. Penelitian serupa tentang persepsi yang dilakukan oleh Novayanti et al., (2017) menunjukan bahwa terdapat hubungan antara ketersediaan informasi terhadap persepsi. Dalam penelitian tersebut menjelaskan bahwa ketersediaan informasi dalam penelitian cukup penting, karena apabila ketersediaan informasi yang diterima oleh masyarakat rendah atau kurang, maka persepsi masyarakat terhadap program tersebut juga akan cukup rendah. Penelitian yang dilakukan Wijayanto (2017) menjelaskan bahwa memberikan informasi kepada masyarakat dan bekerjasama dengan tenaga penyuluh tentang program BPJS Kesehatan merupakan hal yang bermanfaat guna menjamin kesehatan masyarakat.

Menurut Peraturan Menteri Kesehatan No. 001 tahun 2012 menyatakan bahwa rujukan dapat diberikan dengan salah satu syaratnya adalah memberikan informasi terkait keadaan sarana dan prasarana, kompetensi, alur rujukan, serta memberikan pertimbangan kondisi pasien (Kementerian Kesehatan, 2012). Sebagaimana yang telah ditetapkan oleh BPJS Kesehatan dalam Panduan Praktis Sistem Rujukan Berjenjang Tahun 2014 bahwa prosedur pelayanan rujukan harus sesuai dengan alur pelaksanaan rujukan, agar tidak meningkat angka rujukan dari fasilitas kesehatan tingkat pertama (FKTP) ke fasilitas kesehatan tingkat lanjut (FKTL) (BPJS Kesehatan, 2014).

\section{KESIMPULAN DAN SARAN}

\section{Kesimpulan}

Berdasarkan penelitian yang telah 
dilakukan, dapat disimpulkan bahwa tidak terdapat hubungan yang signifikan antara pengetahuan, sikap tenaga kesehatan, dan ketersediaan sarana prasarana dengan persepsi pasien mengenai mengenai ketepatan tindakan rujukan peserta BPJS Kesehatan pada masa pandemi di Puskesmas Jurang Mangu. Informasi tentang rujukan memiliki hubungan yang signifikan dengan persepsi pasien mengenai mengenai ketepatan tindakan rujukan peserta BPJS Kesehatan pada masa pandemi di Puskesmas Jurang Mangu dengan $p$ value $=0,001$. Hal ini menunjukkan bahwa responden yang tidak pernah mendapatkan informasi rujukan memiliki peluang untuk memiliki persepsi tidak sesuai mengenai ketepatan tindakan rujukan dibandingkan dengan responden yang pernah mendapatkan informasi rujukan.

\section{Saran}

Hasil penelitian ini diharapkan dapat menjadi bahan masukan untuk pihak Dinas Kesehatan dan Puskesmas agar dapat melakukan kerja sama dengan BPJS Kesehatan untuk melakukan sosialisasi terkait rujukan BPJS Kesehatan dan dapat menyediakan media informasi mengenai layanan rujukan untuk pasien. Pihak Puskesmas juga perlu melakukan pemberdayaan kader kesehatan sebagai ujung tombak di masyarakat untuk menyampaikan informasi terkait BPJS kepada masyarakat.

\section{DAFTAR PUSTAKA}

1] Alawi, M., Junadi, P. and Latifah, S.N. (2015) 'Analisis Faktor-Faktor yang Berhubungan dengan Tingginya Rujukan Kasus Non Spesialistik Pasien Jaminan Kesehatan Nasional pada Puskesmas di Kabupaten Sukabumi Tahun 2015'.

2] Alfiani, F. and Nurwahyuni, A. (2014) 'Faktor-Faktor yang Berhubungan dengan Kasus Rujukan Rawat Jalan Peserta BPJS Kesehatan KCU Bogor pada Fasilitas Kesehatan Tingkat Pertama di Kota Bogor Tahun 2014'.

3] Ansori, A. (2019) Sistem Kapitasi Puskesmas Perlu Dikaji Ulang.

4] BPJS Kesehatan (2014) 'Panduan Praktis Sistem Rujukan Berjenjang'.

5] BPJS Kesehatan (2015) 'Peraturan Badan Penyelenggara Jaminan Sosial Kesehatan Nomor 2 Tahun 2015 Tentang Norma Penetapan Besaran Kapitasi dan
Pembayaran Kapitasi Berbasis Pemenuhan Komitmen Pelayanan Pada Fasilitas Kesehatan Tingkat Pertama'.

6] BPJS Kesehehatan and Kementerian Kesehatan (2017) Peraturan Bersama Sekretaris Jenderal Kementerian Kesehatan Republik Indonesia dan Direktur Utama Badan Penyelenggara Jaminan Kesehatan Nomor 2 Tahun 2017 Tentang Petunjuk Teknis Penyelenggaraan Pembayaran Kapitasi Berbasis Pemenuhan Komitmen Pelayanan Pa.

7] Dwirayani, D. and Suciati, T. (2017) 'Tingkat Persepsi Dan Faktor Yang Berhubungan Dengan Persepsi Masyarakat Terhadap Program Lumbung Pangan Desa (Suatu Kasus Di Desa Gegesik Kidul Dan Desa Bayanglangu Kidul Kabupaten Cirebon)'.

8] Hanifah, L., Suryoputro, A. and Arso, S.P. (2018) 'Faktor-Faktor yang Berhubungan dengan Persepsi Terhadap Kualitas Layanan Pendaftaran Pasien Rawat Jalan Via SMS Gateway di RSUD Tugurejo Semarang', Jurnal Kesehatan Masyarakat, 6(5), pp. 104-116.

9] Kementerian Kesehatan (2012) 'Peraturan Menteri Kesehatan No. 001 tahun 2012 tentang Sistem Rujukan Pelayanan Kesehatan Perorangan'.

10] Kementerian Kesehatan (2018) Upaya Indonesia Capai Universal Health Coverage di Tahun 2019. Available at: http://sehatnegeriku.kemkes.go.id/baca/rili s-media/20180502/4725818/upayaindonesia-capai-universal-health-coveragetahun-2019/ (Accessed: 12 November 2019).

11] Kurniawati, W. and Rachmayanti, riris diana (2018) 'Identifikasi Penyebab Rendahnya Kepesertaan JKN Pada Pekerja Sektor Informal Di Kawasan Pedesaan', Jurnal administrasi kesehatan Indonesia [Preprint].

12] Novayanti, D. et al. (2017) 'Analisis Faktor-Faktor yang Mempengaruhi Persepsi Masyarakat dalam Pembangunan Hutan Tanaman Rakyat pada KPH Gedong Wani'

13] Omole, N.V., Mora, and Yunusa (2017) 'Knowledge, attitude, and perception of the referral system among tertiary health-care workers in Kaduna metropolis, Nigeri', 
International Journal of Medical Science and Public Health, 6(10), pp. 1481-1488.

14] Purwati (2017) 'Pengambilan Keputusan dalam Pelaksanaan Rujukan Puskesmas sebagai Fasilitas Kesehatan Tingkat Pertama'.

15] Scaioli, G., Schafer and Boerma (2019) 'Patient's perception of communication at the interface between primary and secondary care: a cross-sectional survey in 34 countries', BMC Health Services Research, 19(1018), pp. 2-11.

16] Setiati, S. and Azwar, M.K. (2020) 'COVID-19 and Indonesia', Acta Med Indones-Indones J Intern Med, 52.

17] Setyaningsih, Y. (2012) 'Hubungan Anatara Persepsi Dengan Sikap Masyarakat Terhadap Pengobatan Komplementer Di Kecamatan Grogol Kabupaten Sukoharjo'.
18] Siregar, N.A.S. (2018) 'Faktor-Faktor yang Mempengaruhi Rujukan Pasien Peserta Badan Penyelenggara Jaminan Sosial (BPJS) di Puskesmas Sigambal Kabupaten Labuhanbatu Tahun 2018', Universitas Sumatera Utara [Preprint].

19] Susilo, A. et al. (2020) 'Coronavirus Disease 2019: Tinjauan Literatur Terkini', Jurnal Penyakit Dalam Indonesia, 7(1), p. 45. doi:10.7454/jpdi.v7i1.415.

20] WHO (2020a) Coronavirus Disease 2019 (COVID-19), Situation Report - 42.

21] WHO (2020b) Coronavirus disease 2019 (COVID-19), Situation Report - 70.

22] Wijayanto, W.P. (2017) 'Hubungan Pengetahuan dan Kemampuan Ekonomi Masyarakat terhadap Aksesibilitas BPJS', Aisyah: Jurnal Ilmu Kesehatan, 2(2), pp. 131-140. 